\title{
Switch from antagonist to agonist after addition of a DOTA chelator to a somatostatin analog
}

\author{
Jean Claude Reubi - Judit Erchegyi • Renzo Cescato • \\ Beatrice Waser • Jean E. Rivier
}

Received: 10 December 2009/Accepted: 8 March 2010/Published online: 16 April 2010

(C) Springer-Verlag 2010

\begin{abstract}
Purpose Peptide receptor targeting has become an increasingly attractive method to target tumors diagnostically and radiotherapeutically. Peptides linked to a variety of chelators have been developed for this purpose. They have, however, rarely been tested for their agonistic or antagonistic properties. We report here on a somatostatin antagonist that switched to an agonist upon coupling to a DOTA chelator.

Methods Two novel somatostatin analogs, 406-040-15 and its DOTA-coupled counterpart 406-051-20, with and without cold Indium labeling, were tested for their somatostatin receptor subtypes $1-5\left(\mathrm{sst}_{1}-\mathrm{sst}_{5}\right)$ binding affinity using receptor autoradiography. Moreover, they were tested functionally for their ability to affect $\mathrm{sst}_{2}$ and $\mathrm{sst}_{3}$ internalization in vitro in HEK293 cells stably expressing the human $\mathrm{sst}_{2}$ or $\mathrm{sst}_{3}$ receptor, using an immunofluorescence microscopy-based internalization assay.

Results All three compounds were characterized as pansomatostatin analogs having a high affinity for all five sst. In the $s t_{2}$ internalization assay, all three compounds showed an identical behavior, namely, a weak agonistic effect complemented by a weak antagonistic effect, compatible with the behavior of a partial agonist. Conversely, in the sst $_{3}$ internalization assay, 406-040-15 was a full antagonist
\end{abstract}

J. C. Reubi $(\bowtie) \cdot$ R. Cescato $\cdot$ B. Waser

Division of Cell Biology and Experimental Cancer Research, Institute of Pathology, University of Berne,

PO Box 62, Murtenstrasse 31,

3010 Berne, Switzerland

e-mail: reubi@pathology.unibe.ch

J. Erchegyi · J. E. Rivier

The Clayton Foundation Laboratories for Peptide Biology,

The Salk Institute for Biological Studies,

10010 N. Torrey Pines Road,

La Jolla, CA 92037, USA whereas its DOTA-coupled counterpart, 406-051-20, with and without Indium labeling, switched to a full agonist. Conclusion Adding the DOTA chelator to the somatostatin analog 406-040-15 triggers a switch at sst $_{3}$ receptor from an antagonist to an agonist. This indicates that potential radioligands for tumor targeting should always be tested functionally before further development, in particular if a chelator is added.

Keywords Somatostatin receptors · Agonists . Antagonists · Chelators · Receptor internalization . Functional assays

\section{Introduction}

Somatostatin receptor targeting of tumors has been shown to be a highly successful new method for the diagnosis and radiotherapy of neuroendocrine tumors [1-3]. A prerequisite for that is not only a high density of receptors in the tumors but also the availability of somatostatin radioligands optimized for such investigation.

To obtain suitable radiolabeled tracers, one of the successful strategies of research followed in recent years in nuclear medicine and radiochemistry was to link peptide ligands that were selected for tumor targeting to specific chelator molecules [2-5]. Such chelators have included $\mathrm{N}_{4}$ and HYNIC molecules that will be preferably used for ${ }^{99 \mathrm{~m}}$ Tc imaging, or DTPA and DOTA molecules that can chelate radionuclides such as ${ }^{111} \mathrm{In},{ }^{90} \mathrm{Y},{ }^{177} \mathrm{Lu}$, or ${ }^{68} \mathrm{Ga}$. Since these chelators are relatively large molecules, the peptide-chelator conjugate did often lose some of its receptor binding affinity; therefore, it has always been a prerequisite to confirm that the compounds retain high affinity receptor binding before further development. The 
great variety of radionuclides to choose from gives a wide flexibility to optimize diagnosis and therapy of tumor targets [4]. This synthetic approach has been highly successful for chelator-coupled peptide radioligands derived from various peptides, including somatostatin, bombesin, cholecystokinin, or glucagon-like peptide-1 [4-9].

While candidate compounds have always been tested for their high affinity binding properties in order to make a proper selection of the most suitable ones, it is only recently that scientists became aware that not only the binding but also the functional profile of these analogs might be of importance, in particular to know if the radioligands are agonists or antagonists [10]. According to recent studies [11-13], both agonist and antagonist radioligands may be suitable for in vivo tumor targeting, but for completely different cell biological and molecular reasons.

After binding to the receptor, radioactive agonists are actively taken up into the cells by the receptor as a receptorligand complex. In this way the agonist can accumulate within the cell giving a strong radiation signal [12]. Receptor-mediated radioligand internalization is a powerful, specific, and reversible mechanism that represents the molecular basis for successful peptide receptor targeting in vivo [12]. Importantly, somatostatin receptor internalization appears to be only inducible by somatostatin agonists, but not by somatostatin antagonists $[10,12]$.

However, it was observed recently that peptide receptor targeting in vivo could also be successful without internalization of the receptor-ligand complex [11, 13]. In this case it is necessary to use antagonists rather than agonists; they will also bind with high affinity to the receptor as agonists do, but will not elicit receptor internalization or second messenger activation by themselves $[11,13]$. Such antagonists appear to be good in vivo tracers because they bind to more receptor sites than agonists and dissociate more slowly than agonists, giving also a strong and possibly long-lasting radiation signal [11]. Radioligand antagonists are therefore increasingly being developed in recent times [13-15].

In the present study, we give an example of a somatostatin antagonist that switches its pharmacological profile to an agonist, when linked to a DOTA chelator. This example demonstrates that one cannot predict a priori whether a structurally modified radioligand, including the addition of a chelator, activates or antagonizes the receptor internalization process.

\section{Materials and methods}

Synthesis

Peptides were synthesized by the solid-phase approach on a CS-Bio Peptide Synthesizer (Model CS536). Three equiv- alent excess of Boc-amino acid $(1.2 \mathrm{mmol})$ based on the original substitution of the resin was used for each coupling. Peptide couplings were mediated for $1 \mathrm{~h}$ by DIC/HOBt $(1.2 \mathrm{mmol} / 1.8 \mathrm{mmol})$ in $N, N$-dimethylformamide (DMF). Boc removal was achieved with trifluoroacetic acid (TFA) $\left(60 \%\right.$ in $\mathrm{CH}_{2} \mathrm{Cl}_{2}, 1-2 \%$ ethanedithiol or m-cresol) for $20 \mathrm{~min}$. An isopropyl alcohol (1\% m-cresol) wash followed TFA treatment and then successive washes with triethylamine (TEA) solution $\left(10 \%\right.$ in $\left.\mathrm{CH}_{2} \mathrm{Cl}_{2}\right)$, methanol, triethylamine solution, methanol, and $\mathrm{CH}_{2} \mathrm{Cl}_{2}$ completed the neutralization sequence. The completed peptides were unprotected and cleaved from the resin by anhydrous HF containing the scavengers anisole $(10 \% \mathrm{v} / \mathrm{v})$ and methyl sulfide $(5 \% \mathrm{v} / \mathrm{v})$ for $60 \mathrm{~min}$ at $0^{\circ} \mathrm{C}$. The diethyl ether-precipitated crude peptides were cyclized in $75 \%$ acetic acid $(200 \mathrm{ml})$ by addition of iodine $(10 \%$ solution in methanol) until the appearance of a stable orange color. Forty minutes later, ascorbic acid was added to quench the excess of iodine. For the synthesis of the DOTA-peptide conjugate (406-051-20) the side chain of Lys ${ }^{9}$ (SRIF numbering) was protected with the Fmoc protecting group that stays on after HF cleavage. The solution of DOTANHS ester $(38 \mathrm{mg}, 48 \mu \mathrm{M})$ in DMF $(160 \mu \mathrm{l})$ and $N, N^{\prime}$ diisopropylethylamine (DIPEA) $(40 \mu 1,24 \mu \mathrm{M})$ was added to the solution of the RP-HPLC purified [Lys(Fmoc) $]^{9}$ analog $(\sim 20 \mu \mathrm{M})$ in dry DMF $(800 \mu \mathrm{l})$. The mixture was stirred at room temperature for $5 \mathrm{~h}$. The progress of the reaction was followed by analytical HPLC. After completion of the reaction, a preparative RP-HPLC purification was performed yielding the pure DOTA-[Lys(Fmoc) $]^{9}$ analog. Removal of the Fmoc protecting group from the Lys side chain was achieved with $20 \%$ piperidine/DMF solution resulting in the DOTA-coupled analog, which was further purified by preparative RP-HPLC. The purity of the final peptides determined by analytical RP-HPLC and capillary zone electrophoresis (CZE) was greater than 95\%. Mass spectra (MALDI-MS) were measured on an ABI-Perseptive DE-STR instrument. The observed monoisotopic $(\mathrm{M}+\mathrm{H})^{+}$values of both peptides corresponded with the calculated $(\mathrm{M}+\mathrm{H})^{+}$values.

\section{In-DOTA analog}

The Indium complex formation was carried out according to published procedures [16]. A mixture of $3.04 \mathrm{mg}$ $(\sim 14.8 \mu \mathrm{M})$ 406-051-20 in $6 \mathrm{ml}$ of $0.2 \mathrm{M}$ ammonium acetate buffer (pH 5) was heated with $500 \mu$ of a solution containing $2.01 \mathrm{mg} \mathrm{InCl}_{3}$ in $930 \mu 1$ of $0.2 \mathrm{M}$ ammonium acetate buffer $\left(\mathrm{pH} \mathrm{5)}\right.$ at $95^{\circ} \mathrm{C}$ for $40 \mathrm{~min}$. The complex formation was followed by analytical HPLC (C18 Vydac TP 254 column, eluents: $A=0.1 \%$ TFA in water and $B=$ $60 \%$ acetonitrile in A; gradient: $40 \% \mathrm{~B}$ to $80 \% \mathrm{~B}$ in $40 \mathrm{~min}$. The new product eluted at $68.5 \% \mathrm{~B}$ while the starting 
material eluted at $66.0 \% \mathrm{~B}$. After $40 \mathrm{~min}$ heating the reaction was complete, the solution was cooled to room temperature, and the $\mathrm{pH}$ of the solution was adjusted to acidic with trifluoroacetic acid. Purification of the peptide complex was performed by preparative HPLC affording $1.8 \mathrm{mg}(56 \%)$ of product $\mathrm{In}-406-051-20$ with a purity of 97\% determined by CZE and HPLC. The observed monoisotopic $[\mathrm{M}+\mathrm{H}]^{+} 2,169.70$ corresponded with the calculated $[\mathrm{M}+\mathrm{H}]^{+}$2,069.75.

\section{Reagents}

All reagents were of the best grade available and were purchased from common suppliers. The somatostatin receptor subtype 2 ( sst $_{2}$ )-specific antibody $\mathrm{R} 2-88$ was provided by Dr. Agnes Schonbrunn (Houston, TX, USA) and the sst ${ }_{3}$-specific antibody (SS-850) was purchased from Gramsch Laboratories (Schwabhausen, Germany). The secondary antibody Alexa Fluor 488 goat anti-rabbit $\operatorname{IgG}$ $(\mathrm{H}+\mathrm{L})$ was from Molecular Probes, Inc. (Eugene, OR, USA). SS-28 and the somatostatin analogs 406-040-15, 406-051-20, and In-406-051-20 were synthesized at the Salk Institute. $\left[\mathrm{Tyr}^{3}\right]$-octreotide (TOC) was from Novartis (Basel, Switzerland).

\section{Cell lines}

The HEK293 cell lines expressing either the T7-epitope tagged human $\mathrm{sst}_{2}$ receptor (HEK-sst ${ }_{2}$ ) or the human $\mathrm{sst}_{3}$ receptor (HEK-sst 3 ) were cultured at $37^{\circ} \mathrm{C}$ and $5 \% \mathrm{CO}_{2}$ in DMEM containing $10 \%$ fetal bovine serum (FBS), $100 \mathrm{U} /$ $\mathrm{ml}$ penicillin, $100 \mu \mathrm{g} / \mathrm{ml}$ streptomycin, and $500 \mu \mathrm{g} / \mathrm{ml}$ G418 [10]. All culture reagents were from Gibco BRL, Life Technologies (Grand Island, NY, USA).

\section{Receptor autoradiography}

Cell membrane pellets were prepared from human sst $_{1}$ expressing $\mathrm{CHO}$ cells, sst $_{2^{-}}$, sst $_{3^{-}}$, sst $_{4}$-expressing CCL39 cells, and sst ${ }_{5}$-expressing HEK 293 cells and stored at $-80^{\circ} \mathrm{C}$. Receptor autoradiography was performed on $20-\mu \mathrm{m}$ thick cryostat (Microm HM 500, Walldorf, Germany) sections of the membrane pellets, mounted on microscope slides, and then stored at $-20^{\circ} \mathrm{C}$ as previously described $[14,17]$. For each of the tested compounds, complete displacement experiments with the universal somatostatin radioligand $\left[\mathrm{Leu}^{8}, \mathrm{D}-\mathrm{Trp}^{22},{ }^{125} \mathrm{I}-\mathrm{Tyr}^{25}\right]$-SS-28 $\left({ }^{125} \mathrm{I}\right.$-[LTT]-SS-28) $(2,000 \mathrm{Ci} / \mathrm{mmol}$; Anawa, Wangen, Switzerland $)$ using $15,000 \mathrm{cpm} / 100 \mu \mathrm{l}$ and increasing concentrations of the unlabeled peptide ranging from 0.1 to $1,000 \mathrm{nM}$ were performed. As control, unlabeled SS-28 was run in parallel using the same increasing concentrations. The sections were incubated with ${ }^{125}$ I-[LTT]-SS-28 for $2 \mathrm{~h}$ at room temperature in $170 \mathrm{mmol} / \mathrm{l}$ Tris-HCl buffer (pH 8.2), containing $1 \%$ bovine serum albumin (BSA), $40 \mathrm{mg} / 1$ bacitracin, and $10 \mathrm{mmol} / 1 \mathrm{MgCl}_{2}$ to inhibit endogenous proteases. The incubated sections were washed twice for $5 \mathrm{~min}$ in cold $170 \mathrm{mmol} / 1$ Tris- $\mathrm{HCl}(\mathrm{pH} 8.2$ ) containing $0.25 \%$ BSA. After a brief dip in $170 \mathrm{mmol} / \mathrm{l}$ Tris- $\mathrm{HCl}(\mathrm{pH} 8.2)$, the sections were dried quickly and exposed for 1 week to Kodak BioMax MR film. $\mathrm{IC}_{50}$ values were calculated after quantification of the data using a computer-assisted image processing system as described previously [18]. Tissue standards (autoradiographic $\left[{ }^{125} \mathrm{I}\right]$ and/or $\left[{ }^{14} \mathrm{C}\right]$ microscales, GE Healthcare, Little Chalfont, UK) that contain known amounts of isotope, cross-calibrated to tissue-equivalent ligand concentrations were used for quantification [14, 19].

\section{Immunofluorescence microscopy}

Immunofluorescence microscopy-based internalization assay for $\mathrm{sst}_{2}$ and $\mathrm{sst}_{3}$ was performed as previously described [10]. HEK-sst ${ }_{2}$ or HEK-sst ${ }_{3}$ cells were grown on poly-D-lysine $(20 \mu \mathrm{g} / \mathrm{ml})$ (Sigma-Aldrich, St. Louis, MO, USA) coated $35-\mathrm{mm}$ four-well plates (Cellstar, Greiner Bio-One GmbH, Frickenhausen, Germany). To distinguish whether the tested analogs are agonists or antagonists in respect of stimulating receptor internalization, HEK-sst ${ }_{2}$ cells or HEK-sst ${ }_{3}$ cells were treated for $30 \mathrm{~min}$ at $37^{\circ} \mathrm{C}$ in growth medium, either with vehicle alone (negative control), or, as positive control, with TOC (HEK-sst ${ }_{2}$ ) or SS-28 (HEK-sst ${ }_{3}$ ) at concentrations ranging between $10 \mathrm{nM}$ and $10 \mu \mathrm{M}$, or with $10 \mathrm{nM}$ TOC (HEK$\mathrm{sst}_{2}$ ) or $100 \mathrm{nM} \mathrm{SS}-28$ (HEK-sst ${ }_{3}$ ) in the presence of an excess $(10 \mu \mathrm{M})$ of the somatostatin analogs, or with the somatostatin analogs alone at concentrations ranging between $10 \mathrm{nM}$ and $10 \mu \mathrm{M}$ when the analogs are tested for agonism. The cells were then rinsed twice with PS (100 mM phosphate buffer containing 0.15 M sucrose), fixed and permeabilized for $7 \mathrm{~min}$ with cold methanol $\left(-20^{\circ} \mathrm{C}\right)$, rinsed twice with PS, and then blocked for $60 \mathrm{~min}$ at room temperature with PS containing $0.1 \%$ BSA. Subsequently, the cells were incubated for $60 \mathrm{~min}$ at room temperature either with the $\mathrm{sst}_{2}$ - or $\mathrm{sst}_{3}$-specific primary antibodies R2-88 or SS-850, respectively, diluted 1:1,000 in PS and then washed 3 times for 5 min with PS containing $0.1 \%$ BSA. The cells were then incubated for $60 \mathrm{~min}$ at room temperature in the dark with the secondary antibody Alexa Fluor 488 goat anti-rabbit IgG $(\mathrm{H}+\mathrm{L})$ diluted in PS (1:600), subsequently washed 3 times for 5 min each with PS containing $0.1 \% \mathrm{BSA}$, and embedded with PS/glycerol 1:1 and covered with a glass cover slip. The cells were imaged using a Leica DM RB immunofluorescence microscope and an Olympus DP10 camera. 


\section{Results}

In the course of a search for novel somatostatin antagonists, we designed and synthetized the dodecapeptide 406-040-15 as well as its DOTA-coupled counterpart 406-051-20 (Fig. 1). Both compounds, as well as the In-labeled 406051-20, were tested for their $\mathrm{sst}_{1}-\mathrm{sst}_{5}$ binding profile in transfected cells stably expressing the human $\mathrm{sst}_{1}-\mathrm{sst}_{5}$. All three compounds show a "pan-somatostatin" binding profile, namely, a high affinity binding to all five somatostatin receptor subtypes (Table 1 ). While the DOTA-containing analog 406-051-20 has higher $\mathrm{IC}_{50}$ values, in particular at sst $_{2}$ and sst $_{3}$ (Table 1), the In-labeled 406-051-20 has the lowest $\mathrm{IC}_{50}$ values of all three compounds.

Internalization assays are suitable assays to test for functional responses of somatostatin analogs as receptor targeting drugs, in particular when they are foreseen to become efficient tumor imaging agents. Among the five sst, two of them ( $\mathrm{sst}_{2}$ and $\mathrm{sst}_{3}$ ) are well known for their prominent ability to internalize after agonist stimulation $[20,21]$.

The three compounds were therefore tested first in vitro in HEK-sst ${ }_{2}$ cells for their agonistic and antagonistic properties at the sst $_{2}$ receptor with an immunofluorescence-based internalization assay. This type of assay allows first to evaluate the agonistic efficacy of a compound to trigger receptor internalization when the compound is given alone. If the tested compound shows poor or no efficacy in this assay, it will be tested in a further setting that allows one to distinguish between an inefficient agonist and an antagonist; indeed, when given in excess together with a reference agonist (i.e., natural SS-28 or TOC), the compound will be identified as antagonist if it is able to dose-dependently block the receptor internalization triggered by the reference agonist [10, 12]. As seen in Fig. 2, all three compounds, 406-040-15, 406-051-20, and In-406-051-20, were able to induce $\mathrm{sst}_{2}$ internalization; however, a relatively high dose $(10 \mu \mathrm{M})$ was needed to induce a weak effect. All three

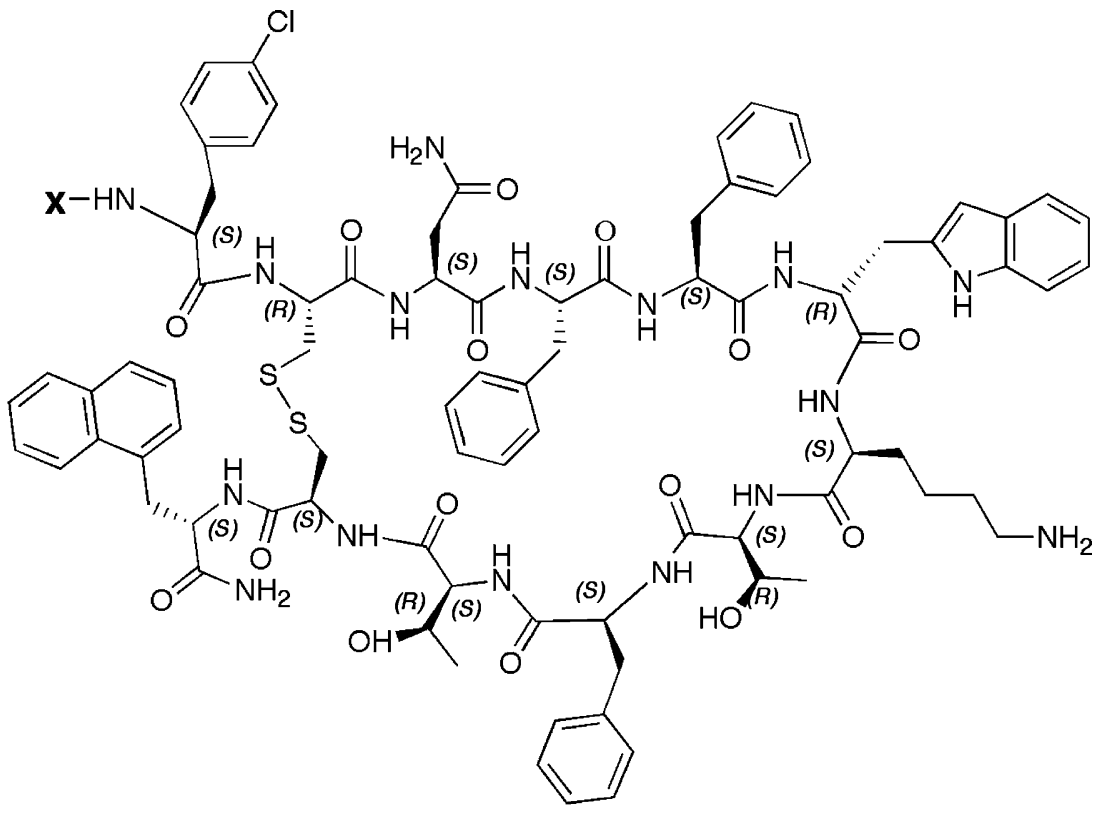

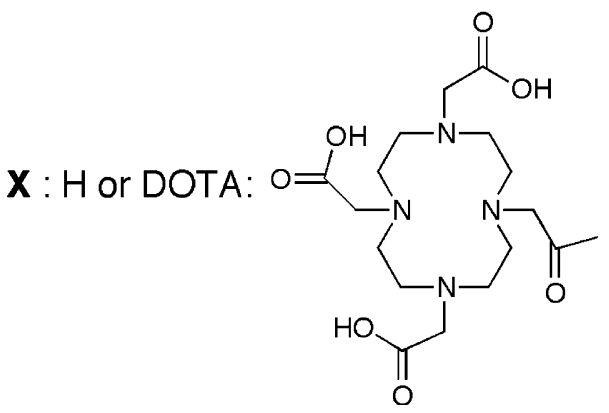

Fig. 1 Structure of 406-040-15 and 406-051-20. 406-040-15: cyclo (2-11) H-Cpa-DCys-Asn-Phe-Phe-DTrp-Lys-Thr-Phe-Thr-Cys-2Nal$\mathrm{NH}_{2}$. 406-051-20: cyclo(2-11) DOTA-Cpa-DCys-Asn-Phe-Phe-
DTrp-Lys-Thr-Phe-Thr-Cys-2Nal-NH $\mathrm{NH}_{2}$. Cpa: 4-Cl-phenylalanine. DOTA: 1,4,7,10-tetraazacyclododecane-1,4,7,10-tetraacetic acid 
Table 1 sst $_{1}-\mathrm{sst}_{5}$ affinity profile of the three somatostatin analogs compared to SS-28 as reference

Data expressed as $\mathrm{IC}_{50}$ in $\mathrm{nM}$ (mean \pm SEM; $n=$ number of experiments in parentheses)

\begin{tabular}{llllll}
\hline Compounds & sst $_{1}$ & sst $_{2}$ & sst $_{3}$ & sst $_{4}$ & sst $_{5}$ \\
\hline SS-28 & $2.0 \pm 0.2(6)$ & $2.1 \pm 0.2(6)$ & $1.8 \pm 0.4(6)$ & $2.0 \pm 0.3(6)$ & $2.8 \pm 0.4(3)$ \\
$406-040-15$ & $2.1 \pm 0.6(3)$ & $6.7 \pm 1.2(3)$ & $9.6 \pm 2.1(3)$ & $5.3 \pm 0.7(3)$ & $9.0 \pm 1.6(3)$ \\
$406-051-20$ & $8.9 \pm 1.9(3)$ & $25 \pm 6.1(3)$ & $29 \pm 6.7(3)$ & $5.8 \pm 1.0(3)$ & $15 \pm 1.0(3)$ \\
In-406-051-20 & $1.5 \pm 0.1(3)$ & $2.9 \pm 0.6(3)$ & $14 \pm 0.7(3)$ & $2.1 \pm 0.1(3)$ & $3.3 \pm 0.3(3)$ \\
\hline
\end{tabular}

compounds were also tested in the presence of TOC, in order to see if they can antagonize TOC-induced receptor internalization. As seen in Fig. 2, the three compounds had a comparable behavior in this assay as well, namely, a minor inhibitory effect on the TOC-induced $\mathrm{sst}_{2}$ internalization. All three compounds are therefore likely to act as partial agonists at $\mathrm{sst}_{2}$ receptor.

The three compounds were also tested functionally for their agonistic or antagonistic properties at the sst $_{3}$ receptor (Figs. 3 and 4) using an immunofluorescence-based sst $_{3}$ receptor internalization assay [10], an assay comparable to the one used for $\mathrm{sst}_{2}$ internalization. In the absence of peptide (negative control), a strong membrane staining of HEK-sst ${ }_{3}$ cells is detectable using a sst $_{3}$-specific antibody (Fig. 3) [10]. In the presence of the agonist SS-28, used as positive control, the $\mathrm{sst}_{3}$ receptor is efficiently internalized in a dose-dependent manner (Fig. 3). In contrast, the dodecapeptide 406-040-15 has no effect alone on sst $_{3}$ internalization (Fig. 4) even at a high concentration of $10 \mu \mathrm{M}$. However, when it is applied at the same concentration in the presence of $100 \mathrm{nM} \mathrm{SS}-28$, it abolishes the SS-28-triggered $\mathrm{sst}_{3}$ internalization completely and therefore acts as a competitive antagonist (Fig. 4). This is in contrast to the DOTA-containing analog 406-051-20 and
Fig. 2 sst $_{2}$ internalization assay to determine whether 406040-15, 406-051-20, and In406-051-20 are agonists or antagonists. HEK-sst ${ }_{2}$ cells were treated either with vehicle (negative control), with $10 \mathrm{nM}$ TOC, a concentration inducing a submaximal internalization effect (positive control), or with $10 \mu \mathrm{M} 406-040-15,406-051-20$, or In-406-051-20 in the absence or presence of $10 \mathrm{nM}$ TOC. Following incubation with the peptides, the cells were processed for immunocytochemistry as described in the "Materials and methods" section. All three analogs, 406040-15, 406-051-20, and In-406-051-20, act as weak agonists but are also able to partially antagonize TOCinduced $\mathrm{sst}_{2}$ internalization

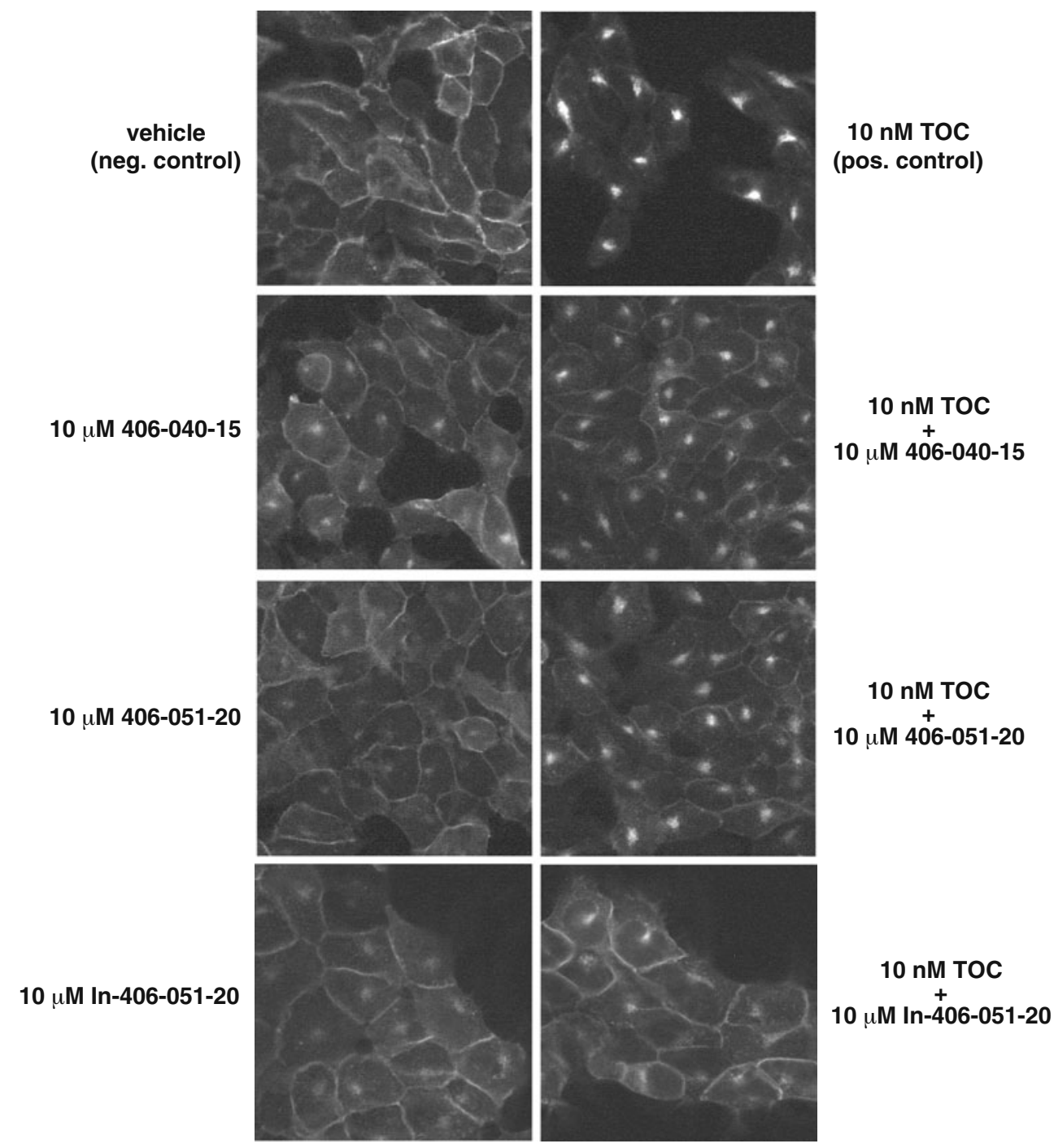



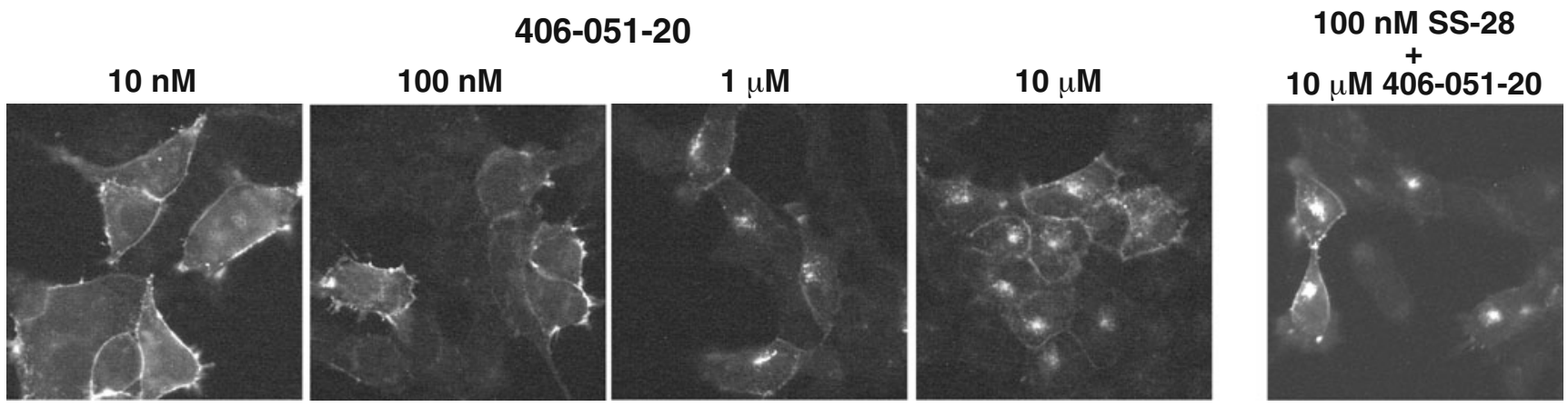

In-406-051-20

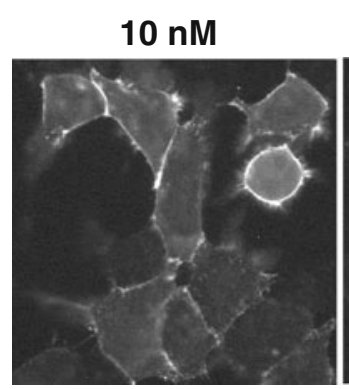

$100 \mathrm{nM}$
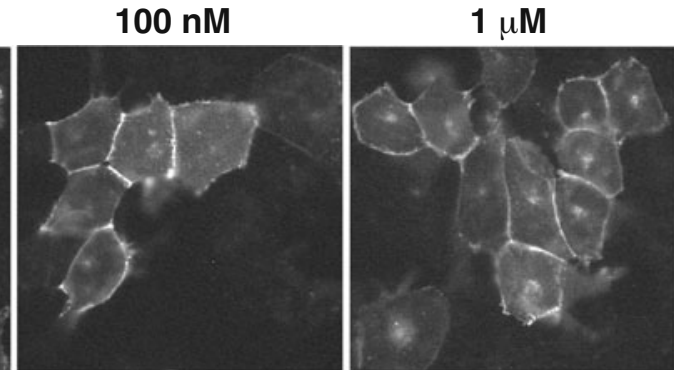

SS-28

$10 \mathrm{nM}$
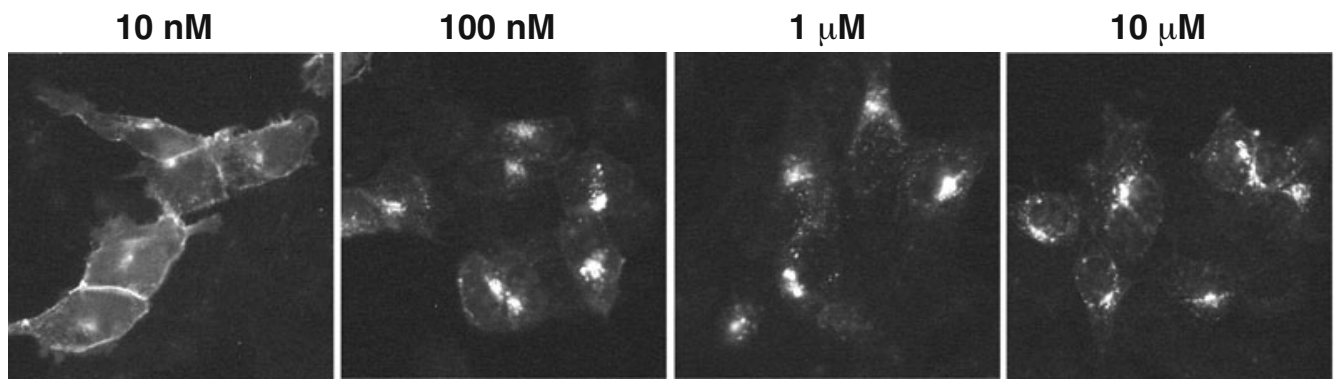

100 nM SS-28

$+$
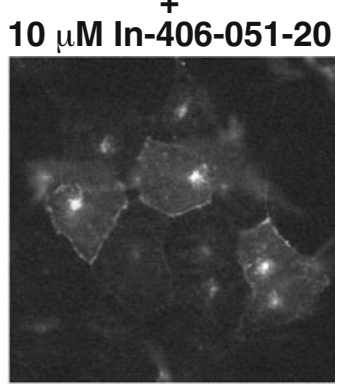

vehicle

(neg. control)

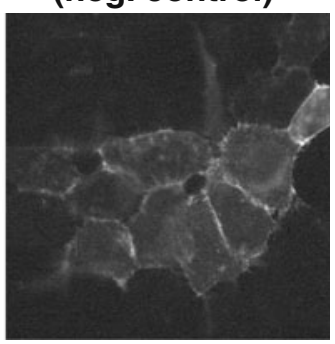

Fig. 3 sst $_{3}$ internalization assay showing the agonistic properties of 406-051-20 and In-406-051-20. HEK-sst 3 cells were treated either with 406-051-20, In-406-051-20, or SS-28 at concentrations ranging between $10 \mathrm{nM}$ and $10 \mu \mathrm{M}$, or with vehicle alone (negative control). To test for antagonism, HEK-sst ${ }_{3}$ cells were treated with $10 \mu \mathrm{M}$ 406051-20 or In-406-051-20 in the presence of $100 \mathrm{nM} \mathrm{SS-28.} \mathrm{Following}$ incubation with the peptides, the cells were processed for immunocytochemistry as described in the "Materials and methods" section. While 406-051-20 and In-406-051-20 act as agonists stimulating sst $_{3}$ internalization, they are not able to antagonize SS-28-induced $\mathbf{s s t}_{3}$ internalization

on receptor internalization, because it has been considered a relevant functional parameter for tumor radiotargeting and for nuclear medicine. Indeed, an efficient internalization of the receptor-ligand complex is necessary in order to allow a radioligand, after binding to the receptor, to be specifically transported into the cells and to accumulate within the tumor cells. There are basically two ways to investigate internalization in vitro: one approach is to use the radioactive ligand and to follow the kinetics of its uptake into the cells [21]. The other approach is to use the nonradioactive ligand and evaluate its effects on the internalization of the receptor itself, by detecting receptor trafficking by immunofluorescence microscopy [10]. The second approach can allow us to differentiate pharmaco- 
Fig. $4 \mathrm{sst}_{3}$ internalization assay showing the antagonistic properties of 406-040-15. HEK-sst 3 cells were treated either with vehicle (negative control), with $100 \mathrm{nM}$ SS-28, a concentration inducing a submaximal internalization effect (positive control), or with $10 \mu \mathrm{M} 406-040-15$ in the absence or presence of 100 nM SS-28. While 406-04015 alone is not able to stimulate sst $_{3}$ internalization, it does efficiently antagonize SS-28induced $\mathrm{sst}_{3}$ internalization

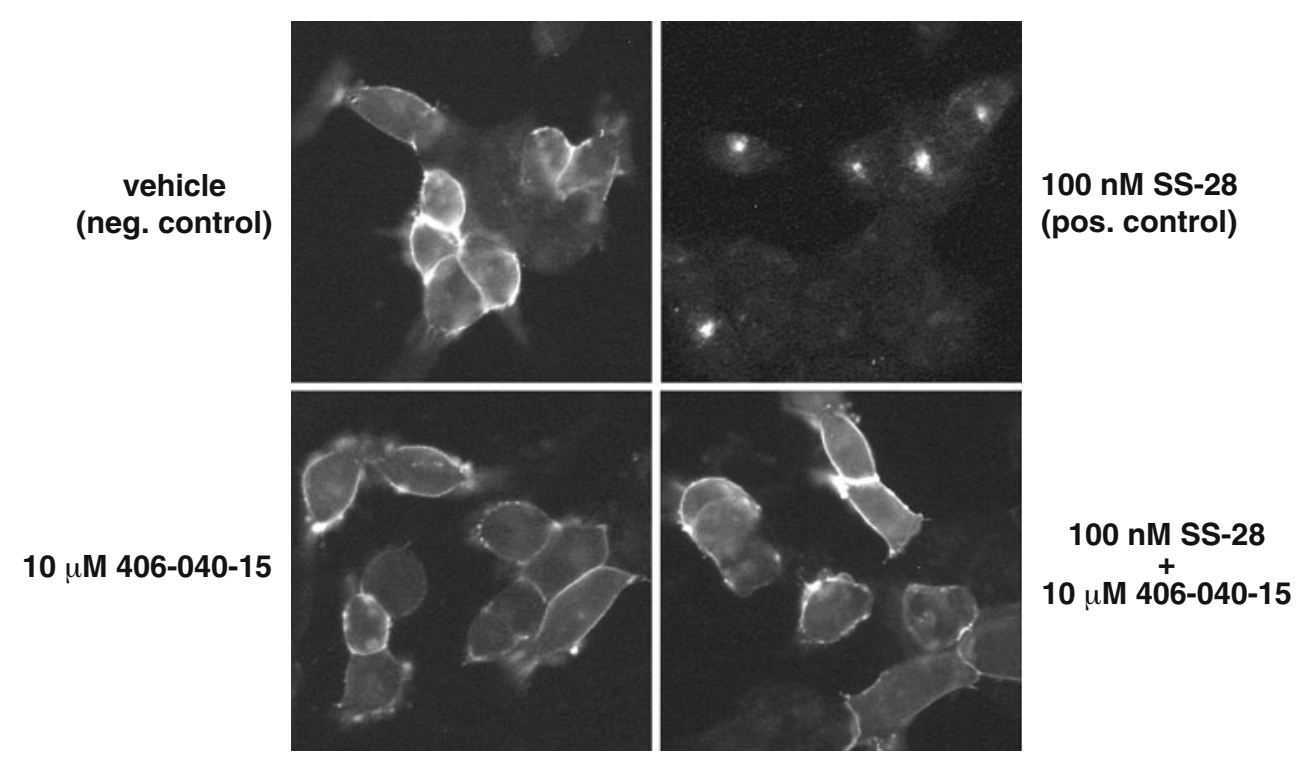

logically if the compound acts as an agonist or an antagonist. This was therefore the method of choice for this study.

The three compounds of interest were characterized in binding experiments as pan-somatostatin analogs, with high affinity binding to all somatostatin receptor subtypes. We have focused on $\mathrm{sst}_{2}$ and $\mathrm{sst}_{3}$ internalization since these are the only two somatostatin subtypes found to have a most efficient receptor internalization capability [20].

The three compounds do not differ significantly in their capacity to induce $\mathrm{sst}_{2}$ internalization. They all have agonistic properties and are relatively weak agonists when compared with TOC. Since they show, in addition, a weak antagonistic behavior to inhibit the $\mathrm{sst}_{2}$ internalization induced by TOC, all three can be considered partial agonists. Therefore, in the sst $_{2}$ system, adding DOTA or In-DOTA to 406-040-15 does not change the functional characteristics of this compound in respect to $\mathrm{sst}_{2}$ internalization.

The situation is completely different for $\mathrm{sst}_{3}$. The DOTA-free analog 406-040-15 is a full and competitive antagonist at $\mathrm{sst}_{3}$, while the DOTA-containing 406-051-20, with or without Indium, switches completely to an agonist in the $\mathrm{sst}_{3}$ receptor internalization assay. This impressive switch in biological function after the addition of a chelator is unexpected and is, at the moment, hard to explain and to understand from a structural point of view. In general, the conversion of a peptide agonist to a peptide antagonist has indeed been so far an empirical tour de force involving such modifications as deletions or the introduction of unnatural amino acids with different chirality. For $\mathbf{s s t}_{2}$, inverting chirality at position 2 and 3 of octreotide (H-DPhe ${ }^{2}-\mathrm{c}\left[\mathrm{Cys}^{3}-\right.$ Phe $^{7}$-DTrp ${ }^{8}$-Lys ${ }^{9}-$ Thr $^{10}{ }^{10}$ Cys $^{14}{ }^{14}-$ Thr $^{15}$-ol, SS-14 numbering) was reported to be the key structural modification converting a somatostatin agonist into a full competitive antagonist at $\mathrm{sst}_{2}$ [22]. For $\mathrm{sst}_{3}$, and as follow-up of the present observation, further investigations may lead to a better understanding of structural requirements for agonism/ antagonism. To our knowledge this is the first example of a peptide antagonist of an hypothalamic releasing factor (thyrotropin-releasing hormone, gonadotropin-releasing hormone, growth hormone-releasing hormone, and corticotropin-releasing hormone) or release inhibiting factor (somatostatin) being switched back to an agonist upon additional substitutions. It has been assumed that peptide competitive antagonists are generated from agonists by limiting the number of available conformations of the agonist or by impeding a conformational change responsible for receptor activation. Lacking structural information at this point, any interpretation of the data would be speculative. NMR studies have been initiated to shed light on this unusual observation.

Structural modifications of a compound after adding a chelator may affect its biological characteristics in several ways: one possibility, having the most dramatic consequences, is the one seen in the present study at the $\mathrm{sst}_{3}$ receptor where a complete switch of biological activity is induced. One other possibility, having no biological consequences, is seen in the present study for the $\mathrm{sst}_{2}$ receptor. Between these two extremes, there are other possible functional changes, ranging from partial agonistic to inverse agonistic activities. These latter functional changes may also affect the radioligand uptake capacity in tumor cells. Indeed, it is known in other systems for instance that partial agonists are much less capable of promoting receptor internalization than full agonists [23, 24].

In-labeled 406-051-20 has a pan-somatostatin binding profile, but despite its high $\mathrm{sst}_{2}$ affinity, has, as partial agonist, poor $\mathrm{sst}_{2}$ internalization characteristics and is therefore unlikely to become a promising targeting tracer for sst $_{2}$-expressing tumors. These characteristics make In- 
labeled 406-051-20 very much comparable to two other pan-somatostatins, KE108 and SOM230, that have been shown previously to have inadequate $\mathrm{sst}_{2}$ targeting properties $[21,25]$.

Before the availability of the recent biological data which showed a role for receptor antagonists in tumor targeting [11, 13], it was considered sufficient to characterize a potential tumor targeting compound by its receptor binding ability and its in vivo tumor uptake properties as radioligand [6-8]. Agonist/antagonist profiles were not, or were only rarely, investigated. Even recently, there have been examples of studies where a DOTA-containing radioligand was considered an antagonist on the basis of sequence homology with its nonchelated peptide, without having been tested itself for antagonism [26], simply assuming that the addition of the chelator would not modify the biological characteristics of the original compound. The main message of this study is therefore to recommend that potential new radioligands for tumor targeting should be extensively tested functionally before further development, even after minor modifications such as the addition of a chelator.

Acknowledgments The project described was supported in part by a grant Number 3200B0-105726/1 from the Swiss National Science Foundation and by Award Number DK059953 from the National Institute of Diabetes and Digestive and Kidney Diseases. The content is solely the responsibility of the authors and does not necessarily represent the official views of the National Institute of Diabetes and Digestive and Kidney Diseases or the National Institutes of Health.

\section{References}

1. Reubi JC. Peptide receptors as molecular targets for cancer diagnosis and therapy. Endocr Rev 2003;24:389-427.

2. van Essen M, Krenning EP, Kam BL, de Jong M, Valkema R, Kwekkeboom DJ. Peptide-receptor radionuclide therapy for endocrine tumors. Nat Rev Endocrinol 2009;5:382-93.

3. Rufini V, Calcagni ML, Baum RP. Imaging of neuroendocrine tumors. Semin Nucl Med 2006;36:228-47.

4. Reubi JC, Maecke HR. Peptide-based probes for cancer imaging. J Nucl Med 2008;49:1735-8.

5. Nock B, Nikolopoulou A, Chiotellis E, Loudos G, Maintas D, Reubi JC, et al. [99mTc]Demobesin 1, a novel potent bombesin analogue for GRP receptor-targeted tumour imaging. Eur J Nucl Med Mol Imaging 2003;30:247-58.

6. Behr TM, Jenner N, Béhé M, Angerstein C, Gratz S, Raue F, et al. Radiolabeled peptides for targeting cholecystokinin-B/gastrin receptor-expressing tumors. J Nucl Med 1999;40:1029-44.

7. Gotthardt M, Fischer M, Naeher I, Holz JB, Jungclas H, Fritsch HW, et al. Use of the incretin hormone glucagon-like peptide-1 (GLP-1) for the detection of insulinomas: initial experimental results. Eur J Nucl Med Mol Imaging 2002;29:597-606.

8. Wild D, Schmitt JS, Ginj M, Mäcke HR, Bernard BF, Krenning E, et al. DOTA-NOC, a high-affinity ligand of somatostatin receptor subtypes 2, 3 and 5 for labelling with various radiometals. Eur J Nucl Med Mol Imaging 2003;30:1338-47.

9. Zhang H, Schuhmacher J, Waser B, Wild D, Eisenhut M, Reubi JC, et al. DOTA-PESIN, a DOTA-conjugated bombesin derivative designed for the imaging and targeted radionuclide treatment of bombesin receptor-positive tumours. Eur J Nucl Med Mol Imaging 2007;34:1198-208.

10. Cescato R, Schulz S, Waser B, Eltschinger V, Rivier J, Wester HJ, et al. Internalization of sst2, sst3 and sst5 receptors: effects of somatostatin agonists and antagonists. J Nucl Med 2006;47:50211.

11. Ginj M, Zhang H, Waser B, Cescato R, Wild D, Wang X, et al. Radiolabeled somatostatin receptor antagonists are preferable to agonists for in vivo peptide receptor targeting of tumors. Proc Natl Acad Sci USA 2006;103:16436-41.

12. Waser B, Tamma ML, Cescato R, Maecke HR, Reubi JC. Highly efficient in vivo agonist-induced internalization of sst2 receptors in somatostatin target tissues. J Nucl Med 2009;50:936-41.

13. Cescato R, Maina T, Nock B, Nikolopoulou A, Charalambidis D, Piccand $\mathrm{V}$, et al. Bombesin receptor antagonists may be preferable to agonists for tumor targeting. J Nucl Med 2008;49:318-26.

14. Cescato R, Erchegyi J, Waser B, Piccand V, Maecke HR, Rivier $\mathrm{JE}$, et al. Design and in vitro characterization of highly sst2selective somatostatin antagonists suitable for radiotargeting. J Med Chem 2008;51:4030-7. doi:10.1021/jm701618q10.1021/ jm701618q.

15. Mansi R, Wang X, Forrer F, Kneifel S, Tamma ML, Waser B, et al. Evaluation of a 1,4,7,10-tetraazacyclododecane-1,4,7,10-tetraacetic acid-conjugated bombesin-based radioantagonist for the labeling with single-photon emission computed tomography, positron emission tomography, and therapeutic radionuclides. Clin Cancer Res 2009;15:5240-9.

16. Edreira M, Melendez-Alafort L, Mather SJ. Optimization of the small-scale synthesis of DOTA-Tyr3-octreotide. Nucl Med Commun 2002;23:493-9.

17. Reubi JC, Schär JC, Waser B, Wenger S, Heppeler A, Schmitt J, et al. Affinity profiles for human somatostatin receptor subtypes sst1-sst5 of somatostatin radiotracers selected for scintigraphic and radiotherapeutic use. Eur J Nucl Med 2000;27:273-82.

18. Reubi JC, Kvols LK, Waser B, Nagorney D, Heitz PU, Charboneau JW, et al. Detection of somatostatin receptors in surgical and percutaneous needle biopsy samples of carcinoids and islet cell carcinomas. Cancer Res 1990;50:5969-77.

19. Erchegyi J, Cescato R, Grace CR, Waser B, Piccand V, Hoyer D, et al. Novel, potent, and radio-iodinatable somatostatin receptor 1 (sst1) selective analogues. J Med Chem 2009;52:2733-46.

20. Olias G, Viollet C, Kusserow H, Epelbaum J, Meyerhof W. Regulation and function of somatostatin receptors. J Neurochem 2004;89:1057-91.

21. Ginj M, Zhang H, Eisenwiener KP, Wild D, Schulz S, Rink H, et al. New pansomatostatin ligands and their chelated versions: affinity profile, agonist activity, internalization, and tumor targeting. Clin Cancer Res 2008;14:2019-27.

22. Bass RT, Buckwalter BL, Patel BP, Pausch MH, Price LA, Strnad $\mathrm{J}$, et al. Identification and characterization of novel somatostatin antagonists [published erratum appears in Mol Pharmacol 1997 Jan;51(1):170]. Mol Pharmacol 1996;50:709-15.

23. Schlag BD, Lou Z, Fennell M, Dunlop J. Ligand dependency of 5-hydroxytryptamine $2 \mathrm{C}$ receptor internalization. J Pharmacol Exp Ther 2004;310:865-70.

24. Corbani M, Gonindard C, Meunier JC. Ligand-regulated internalization of the opioid receptor-like 1: a confocal study. Endocrinology 2004;145:2876-85.

25. Liu Q, Cescato R, Dewi DA, Rivier J, Reubi JC, Schonbrunn A. Receptor signaling and endocytosis are differentially regulated by somatostatin analogs. Mol Pharmacol 2005;68:90-101.

26. Edwards WB, Xu B, Akers W, Cheney PP, Liang K, Rogers BE, et al. Agonist-antagonist dilemma in molecular imaging: evaluation of a monomolecular multimodal imaging agent for the somatostatin receptor. Bioconjug Chem 2008;19:192-200. 